\title{
PENGARUH PENGETAHUAN KEUANGAN DAN SIKAP KEUANGAN TERHADAP LOCUS OF CONTROL DAN PERILAKU PENGELOLAAN KEUANGAN MAHASISWA EKONOMI
}

\author{
Tifani Enno Pradiningtyas dan Fitri Lukiastuti* \\ STIE Bank BPD Jateng, Semarang
}

\begin{abstract}
Abstrak: Penelitian ini bertujuan menganalisis faktor-faktor yang mempengaruhi perilaku pengelolaan keuangan pada 100 mahasiswa ekonomi perguruan tinggi swasta Kota Semarang. Data dianalisis menggunakan analisis jalur. Hasil penelitian menunjukkan bahwa pengetahuan keuangan dan sikap keuangan berpengaruh positif terhadap locus of control selanjutnya pengetahuan keuangan, sikap keuangan dan locus of control berpengaruh positif terhadap perilaku pengelolaan keuangan mahasiswa. Locus of control mampu memediasi pengaruh pengetahuan dan sikap keuangan terhadap perilaku pengelolaan keuangan mahasiswa. Proses perubahan cara pikir mahasiswa tentang pengendalian hidup terjadi dari dalam proses pemikiran mahasiswa itu sendiri.

Kata Kunci: pengetahuan keuangan, sikap keuangan, locus of control, perilaku pengelolaan keuangan
\end{abstract}

Abstract: This study aims to analyze the factors that influence financial management behavior of 100 economic students of private universities in Semarang City. The analysis tool uses path analysis. The results showed that financial knowledge and financial attitudes had a positive effect on the locus of control, furthermore, financial knowledge, financial attitude, and locus of control had a positive effect on student financial management behavior. Locus of control is able to mediate the influence of financial knowledge and attitudes towards student financial management behavior. The students' thought transition occurs in the internal consideration of themselves.

Keywords: financial knowledge, financial attitude, locus of control, financial management behavior

\footnotetext{
* Surel Korespondensi Penulis: fitri111269@stiebankbpdjateng.ac.id

DOI: $10.24252 /$ minds.v6i1.9274
}

ISSN-E: 2597-6990

http://journal.uin-alauddin.ac.id/index.php/minds 


\section{PENDAHULUAN}

Otoritas Jasa Keuangan tahun 2016 menyampaikan bahwa tingkat pengetahuan keuangan masyarakat Indonesia masih berada pada angka $28 \%$ sementara Malaysia 66\%, Singapura mencapai 98\%, dan Thailand mencapai angka $73 \%$. Salah satu faktor penyebab rendahnya pengetahuan keuangan tersebut adalah kondisi geografis Indonesia yang pada umumnya sekitar $60 \%$ berada pada daerah perdesaan. Ditambah dengan hasil survei nasional OJK yang menunjukan bahwa terdapat $67,82 \%$ inklusi keuangan masyarakat yang menggunakan produk dan layanan keuangan, namum hanya 29,66\% literasi keuangan penduduk yang memiliki pengetahuan, ketrampilan, kepercayaan, sikap dan perilaku yang memadai dalam menggunakan produk dan layanan keuangan. Bank Indonesia juga menyatakan bahwa saat ini masih banyak individu yang perlu diberikan edukasi keuangan agar individu mampu meminimalisir resiko terkait dengan permasalahan keuangan. Edukasi yang dianggap penting dirasa karena beberapa faktor diantaranya, terbatasnya akses individu terhadap lembaga keuangan yang ada guna meningkatkan produktivitas untuk menuju kesejahteraan dan kemandirian. Selain itu, minimnya minat individu untuk menabung menunjukkan kurva yang rendah pula tentang kesadaran individu untuk membiasakan diri membuat dan memiliki perencanaan keuangan. Banyaknya masyarakat yang tidak mengerti tentang keuangan menyebabkan banyak masyarakat yang mengalami kerugian, baik akibat penurunan kondisi perekonomian dan inflasi atau karena berkembangnya sistem ekonomi yang cenderung boros karena masyarakat semakin konsumtif (Ida dan Dwinta, 2010).

Untuk mencapai financial management behavior, maka diperlukan financial attitude yang positif untuk diimplementasikan secara langsung. Sikap terhadap uang merupakan bentuk persepsi dari individu mengenai uang berdasarkan pengalaman dan keadaan yang pernah dialami dalam hidupnya (Taneja, 2012). Hasil penelitian yang dilakukan oleh Irine dan Damanik (2016) menunjukan bahwa financial attitude memiliki pengaruh positif signifikan terhadap financial management behavior. Hal ini menyatakan bahwa terdapat hubungan antara sikap keuangan dengan permasalahan yang ada pada keuangan. Penelitian tersebut menyimpulkan bahwa sikap keuangan individu juga mempengaruhi cara individu mengatur dirinya berperilaku dalam keuangan. Penelitian ini bertujuan menganalisis faktor-faktor yang mempengaruhi perilaku pengelolaan keuangan pada 100 mahasiswa ekonomi perguruan tinggi swasta Kota Semarang

\section{TINJAUAN TEORITIS}

\section{Teori Kognitif Sosial (SCT)}

Konsep utama dari teori kognitif sosial adalah pengertian tentang obvervational learning atau proses belajar dengan mengamati. Jika ada seorang "model" di dalam lingkungan seorang individu, misalnya saja teman atau anggota keluarga di dalam lingkungan internal, atau di lingkungan publik 
seperti para tokoh publik di bidang berita dan hiburan, proses belajar dari individu ini akan terjadi melalui cara memperhatikan model tersebut. Terkadang perilaku seseorang bisa timbul hanya karena proses modeling. Modeling atau peniruan merupakan "the direct, mechanical reproduction of behavior, reproduksi perilaku yang langsung dan mekanis (Baran \& Davis, 2000: 184). Baranowski, Perry, dan Parcel (1997) menyatakan bahwa "reinforcement is the primary construct in the operant form of learning" (p.161) - proses penguatan sebagai bentuk utama dari cara belajar seseorang. Proses penguatan juga merupakan konsep sentral dari proses belajar sosial. Di dalam teori kognitif sosial, penguatan bekerja melalui proses efek menghalangi (inhibitory effects) dan efek membiarkan (disinhibitory effects).

Menurut Bandura (1986), vicarious reinforcement terjadi karena adanya konsep pengharapan hasil (outcome expectations) dan harapan hasil (outcome expectancies). Outcome expectations menunjukkan bahwa ketika kita melihat seorang model diberi penghargaan dan dihukum, kita akan berharap mendapatkan hasil yang sama jika kita melakukan perilaku yang sama dengan model. Seperti dikatakan oleh Baranowski dkk (1997), "People develop expectations about a situation and expectations for outcomes of their behavior before they actually encounter the situation" (p. 162) -- orang akan mengembangkan pengharapannya tentang suatu situasi dan pengharapannya untuk mendapatkan suatu hasil dari perilakunya sebelum ia benar-benar mengalamai situasi tersebut. Selanjutnya, seseorang mengikat nilai dari pengharapan tersebut dalam bentuk outcome expectancies - harapan akan hasil.

Teori kognitif sosial juga mempertimbangkan pentingnya kemampuan sang "pengamat" untuk menampilkan sebuah perilaku khusus dan kepercayaan yang dipunyainya untuk menampilkan perilaku tersebut. Kepercayaan ini disebut dengan self-efficacy atau efikasi diri (Bandura, 1977a) dan hal ini dipandang sebagai sebuah prasyarat kritis dari perubahan perilaku.

\section{Teori Perilaku yang Direncanakan (TPB)}

Menurut Wahyono (2014) Theory of Planned Behavior (TPB) merupakan perluasan dari Theory of Reasoned Action (TRA). Dalam TRA dijelaskan bahwa niat seseorang terhadap perilaku dibentuk oleh dua faktor utama yaitu attitude toward the behavior dan subjective norms (Fishbein dan Ajzen, 1975), sedangkan dalam TPB ditambahkan satu faktor lagi yaitu perceived behavioral control (Ajzen, 1991). TPB sangat sesuai digunakan untuk menjelaskan berbagai perilaku di dalam kewirausahaan. Sebagaimana dikatakan oleh Ajzen (1991) bahwa TPB is suitable to explain any behavior which requires planning, such as entrepreneurship (TPB cocok untuk menjelaskan perilaku apa pun yang memerlukan perencanaan, seperti kewirausahaan).

\section{Perilaku Pengelolaan Keuangan (Financial Management Behavior)}

Perilaku pengelolaan keuangan adalah kemampuan seseorang dalam mengatur yaitu mengatur sebuah perencanaan, penganggaran, pemeriksaan, 
pengelolaan, pengendalian, pencarian dan penyimpanan dana keuangan seharihari (Kholilah dan Iramani, 2013). Besarnya hasrat individu untuk memenuhi kebutuhan hidup sesuai dengan tingkat pendapatan perkapita adalah pemicu munculnya financial management behavior.

Pengetahuan Keuangan (Financial Knowledge)

Pengetahuan mengacu pada apa yang diketahui individu tentang masalah keuangan pribadi, yang diukur dengan tingkat pengetahuan mereka tentang berbagai konsep keuangan pribadi (Marsh, 2006). Financial knowledge adalah penguasaan seseorang atas berbagai hal tentang dunia keuangan (Kholilah dan Iramani, 2013) Pemuda belajar tentang uang sebagian besar dari sekolah dan orang tua, dengan penekanan pada penghematan (Chowa et.al, 2012). Pada perkembangannya, pengetahuan mengenai keuangan mulai diperkenalkan di berbagai jenjang pendidikan. Terdapat berbagai sumber pengetahuan yang dapat diperoleh, termasuk pendidikan formal, seperti program sekolah tinggi atau kuliah, seminar dan kelas pelatihan di luar sekolah, serta sumber-sumber informal, seperti dari orang tua, teman, dan lingkungan pekerjaan (Ida dan Dwinta, 2010).

\section{Sikap Keuangan (Financial Attitude)}

Pengertian sikap keuangan menurut Pankow (2003) sebagaimana dikutip oleh Humaira dan Sagoro (2018) sesuai pengertian yang dikembangkan oleh Klontz dkk (2011), yaitu diartikan sebagai keadaan pikiran, pendapat, serta penilaian tentang keuangan. Menurut Jodi \& Phyllis (1998) dalam Rajna et al., (2011) Sikap keuangan adalah kecenderungan psikologis yang diekspresikan ketika mengevaluasi praktik manajemen keuangan yang direkomendasikan dengan beberapa tingkatan kesepakatan dan ketidaksepakatan.

Lokus Kendali (Locus Of Control)

Menurut Rotter dalam Robbins (2008: 138), locus of control mengandung arti tingkat di mana individu yakin bahwa mereka adalah penentu nasib mereka sendiri dan merupakan tindakan dimana individu menghubungkan peristiwaperistiwa dalam kehidupannya dengan tindakan atau kekuatan di luar kendalinya.

Jadi, locus of control adalah sikap seseorang yang meyakini bahwa apa yang terjadi dalam dirinya merupakan akibat dari tindakannya sendiri. Locus of control merupakan suatu konsep yang menuju pada keyakinan individu mengenai peristiwa yang terjadi dalam hidupnya. Locus of control menggambarkan seberapa jauh seseorang memandang hubungan antara perbuatan yang dilakukan (action) dengan akibat/hasil. Locus of control berhubungan dengan sikap kerja dan citra diri seseorang.

Rotter dalam Robbins (2008: 140), membedakan Locus of control menjadi dua, yaitu: 1) locus of control internal; Internality (I). Adalah individu-individu yang yakin bahwa mereka merupakan pemegang kendali atas apa pun yang terjadi pada diri mereka. Hasil adalah dampak langsung dari tindakannya; 2) locus of control eksternal ; Powerful Others $(P)$ dan Chance (C). Adalah individu99 
individu yang yakin bahwa apa pun yang terjadi pada diri mereka dikendalikan oleh kekuatan luar seperti keberuntungan atau kesempatan.

\section{Pengembangan Hipotesis}

\section{Pengaruh Pengetahuan Keuangan Terhadap Locus Of Control Mahasiswa}

Untuk menangani permasalahan keuangan pribadi yang sistematis dan dapat berhasil, individu membutuhkan sebuah pengetahuan terhadap uang. Pengetahuan keuangan tidak hanya membantu individu menggunakan uang secara bijak, individu yang sering dihadapkan dengan situasi trade-off dimana individu dipaksa keadaan untuk mengorbankan kepentingan seseorang demi kepentingan orang lain. Masalah trade-off terjadi karena individu dibatasi oleh kemampuan keuangannya untuk mendapatkan setiap barang yang diinginkan.

Dengan keadaan tersebut, pengendalian diri akan menjadikan individu untuk mencoba berfikir dan berperilaku dalam penggunaan uang. Pengetahuan keuangan yang baik akan membentuk pengendalian diri individu lebih baik pula. Hal ini sejalan dengan penelitian yang dilakukan oleh Pritazahara (2015), yang menyatakan bahwa pengetahuan keuangan memiliki pengaruh positif namun tidak signifikan pada locus of control individu. Menurutnya, peran pengetahuan keuangan membantu dalam pengendalian diri individu namun besar pengaruhnya tidak terlalu besar dalam tindakan yang terbentuk di lingkungan. Berdasarkan penelitian ini, penelitian ini merumuskan hipotesis sebagai berikut :

H1 : pengetahuan keuangan memiliki pengaruh yang positif terhadap locus of control

\section{Pengaruh Sikap Keuangan Terhadap Locus Of Control Mahasiswa}

Sikap keuangan lebih mengarah pada jalan pemikiran individu, pendapatan dan penilaian individu tentang praktik keuangan. Individu yang bersikap rasional dan percaya diri dalam hal keuangan akan mempengaruhi pengendalian dirinya. Karena pada dasarnya, locus of control mengacu pada sejauh mana individu mampu percaya bahwa dirinya dapat mengendalikan peristiwa - peristiwa yang mempengaruhi hidupnya. Hal ini didukung oleh penelitian yang dilakukan Hayhoe, et all (1999) dalam penelitian Herdjiono (2016) menyatakan bahwa ada hubungan positif antara sikap keuangan dan tingkat keuangan. Dengan demikian, dapat dikatakan bahwa sikap keuangan seseorang juga menjadi faktor yng mempengaruhi cara seseorang mengendalikan dirinya. Berdasarkan landasan teori dan hasil penelitian sebelumnya, maka penelitian ini merumuskan hipotesis sebagai berikut :

H2 : Sikap keuangan memiliki pengaruh yang positif terhadap locus of control

Pengaruh Pengetahuan Keuangan Terhadap Perilaku Pengelolaan Keuangan Mahasiswa

Pengetahuan keuangan sangat dibutuhkan oleh setiap individu dalam mengelola keuangan pribadinya. Saat individu memiliki pengetahuan keuangan 
yang baik, individu akan mampu melakukan pengelolaan keuangan yang cerdas berupa pencatatan dan penganggaran, perbankan dan penggunaan kredit, simpanan dan pinjaman, pembayaran pajak, membuat pengeluaran yang krusial, membeli dan mengerti asuransi, investasi, dan rencana dana pensiun (Kholilah dan Iramani, 2013). Pengetahuan keuangan tidak hanya mampu menggunakan uang, namun dapat memberi manfaat pada ekonomi. Individu dengan pengetahuan finansial lebih tinggi mampu membuat keputusan yang baik dalam hidupnya dengan demikian individu berperan dalam meningkatkan keamanan ekonomi (Hilgert dan Hogarth, 2003).

Penelitian Ida dan Dwinta (2010) menerangkan bahwa pengetahuan keuangan mampu menjadi salah satu faktor kesuksesan dalam mengelola keuangan individu. Hal ini didasari dengan hasil uji regresi yang menunjukan nilai sig. variabel financial knowledge sebesar 0,025 menunjukkan hipotesis diterima, sehingga terdapat pengaruh financial knowledge terhadap financial management behavior. Didukung dengan penelitian yang dilakukan oleh Rustiaria (2017), dalam penelitiannya terdapat hasil positif antara financial knowledge dan perilaku pengelolaan keuangan. Sehingga semakin baik pengetahuan tentang keuangan maka semakin baik pula individu dalam mengelola keuangannya. Hipotesis ketiga yang terbentuk dalam penelitian ini adalah :

H3 : Pengetahuan keuangan memiliki pengaruh positif terhadap perilaku pengelolaan keuangaan.

Pengaruh Sikap Keuangan Terhadap Perilaku Pengelolaan Keuangan Mahasiswa

Sikap keuangan juga dirasa tidak kalah penting dalam pengelolaan keuangan pribadi. Dengan mempunyai sikap keuangan yang baik, maka individu akan dapat mengelola keuangan dengan baik pula. Tanpa menerapkan hal tersebut, dirasa akan sulit bagi individu mempunyai surplus uang yang dialokasikan untuk tabungan masa depan, apalagi memiliki modal untuk berinvestasi. Sikap biasanya di ukur dengan tanggapan individu atas opininya terhadap uang sedangkan perilaku pengelolaan keuangan mengarah pada bagaimana individu berperilaku yang kaitannya dengan hal keuangan pribadi yang diukur dengan tindakan individu tersebut.

Penelitian terdahulu yang membahas mengenai pengaruh pengaruh sikap keuangan terhadap perilaku pengelolaan keuangan telah diteliti oleh beberapa peneliti diantaranya Irine dan Damanik (2016) serta Puneet dan Medury (2014). Menurut Irine dan Damanik (2016), menjelaskan bahwa ada pengaruh antara financial atittude dengan financial management behavior. Serta Puneet dan Medury (2014), mendukung penelitian sebelumnya bahwa sikap keuangan mempengaruhi secara signifikan pada perilaku pengelolaan keuangan. Dengan demikian hipotesis ke empat yang diajukan dalam penelitian ini adalah :

H4 : Sikap keuangan memiliki pengaruh yang positif terhadap perilaku pengelolaan keuangan mahasiswa. 


\section{Pengaruh Locus Of Control Terhadap Perilaku Pengelolaan Keuangan Mahasiswa}

Locus of control diperlukan karena merupakan perspektif seseorang pada suatu peristiwa, apakah peristiwa tersebut dapat dipengaruhi oleh tindakan individu atau orang lain. Rotter (1966) menyatakan bahwa dalam orientasinya, locus of control dibagi menjadi dua yaitu locus of control internal dan locus of control external. Individu dengan locus of control internal lebih percaya diri akan tindakannya dan percaya bahwa semua terjadi tergantung pada dirinya sendiri. Sedangkan individu dengan locus of control external akan percaya bahwa semua tindakan dan kejadian dapat terjadi bergantung pada taksir dan lingkungan. Locus of control dalam pengelolaan keuangan merupakan sebuah aktivitas untuk melakukan tindakan berupa proteksi - proteksi diri seperti berhemat, mengendalikan perilaku konsumtif, dan tindakan lainnya.

Bukti empiris dari penelitian yang dilakukan oleh Dwiastanti (2017), menunjukan bahwa individu yang memiliki pengendalian diri yang baik akan menunjukan perilaku pengelolaan keuangan yang lebih baik pula. Misalnya, seorang individu yang memiliki pengendalian diri yang baik akan membuat rencana anggaran yang matang termasuk bagaimana mengelola tabungan, investasi dan pembayaran kredit. Jadi jika memang demikian, terkait dengan indikator yang digunakan dalam penelitian ini, peneliti merumuskan hipotesis sebagai berikut :

H5 : Locus of control mempunyai pengaruh yang positif terhadap perilaku pengelolaan keuangan.

Pengaruh Pengetahuan Keuangan Terhadap Perilaku Pengelolaan Keuangan Mahasiswa yang Dimediasi oleh Locus Of Control

Pendidikan keuangan akan bernilai sangat kecil jika tidak didampingi dengan tanggung jawab pribadi. Perry dan Morris (2005) berpendapat bahwa individu mungkin tidak memanfaatkan sepenuhnya pengetahuan atau sumber daya keuangan mereka kecuali mereka merasa bahwa mereka mengendalikan nasib mereka sendiri. Pengetahuan keuangan yang digunakan secara seimbang dengan pengendalian diri individu akan membantu dalam pengelolaan keuangan yang bijak. Didukung dengan penelitian yang dilakukan oleh Nguyen dan Thao (2015), Kholilah dan Iramani (2013), Nur Riska (2018) dan Kurniawati dan Lestari (2017) yang menunjukan hasil bahwa locus of control memediasi pengaruh financial knowledge terhadap financial management behavior. Dengan demikian, peneliti mengajukan rumusan hipotesis sebagai berikut :

H6 : Locus of control memediasi pengaruh pengetahuan keuangan terhadap perilaku pengelolaan keuangan.

Pengaruh Sikap Keuangan Terhadap Perilaku Pengelolaan Keuangan Mahasiswa yang Dimediasi Oleh Locus Of Control

Sikap keuangan adalah keadaan pikiran, pendapat, dan penilaian seseorang terhadap keuangan pribadinya yang kemudian diterapkan pada suatu tindakan. Sikap terhadap uang cenderung mengarah pada psikologis yang diekspresikan ketika 
melakukan praktik pengelolaan keuangan dengan beberapa tingkatan kesepakatan dan ketidaksepakatan. Dalam praktik tersebut, sikap membutuhkan inisiatif tinggi yang muncul dari dalam diri individu dan berfikikir efektif agar pengelolaan keuangan yang terbentuk lebih tertata. Semakin baik sikap individu tentang keuangan akan memberikan dukungan kepada pengendalian diri dalam mengambil tindakan atau keputusan. Berdasarkan sikap keuangan yang dibantu dengan pengendalian diri individu, peneliti merumuskan hipotesis sebagai berikut :

H7 : Locus of control memediasi pengaruh sikap keuangan terhadap perilaku pengelolaan keuangan.

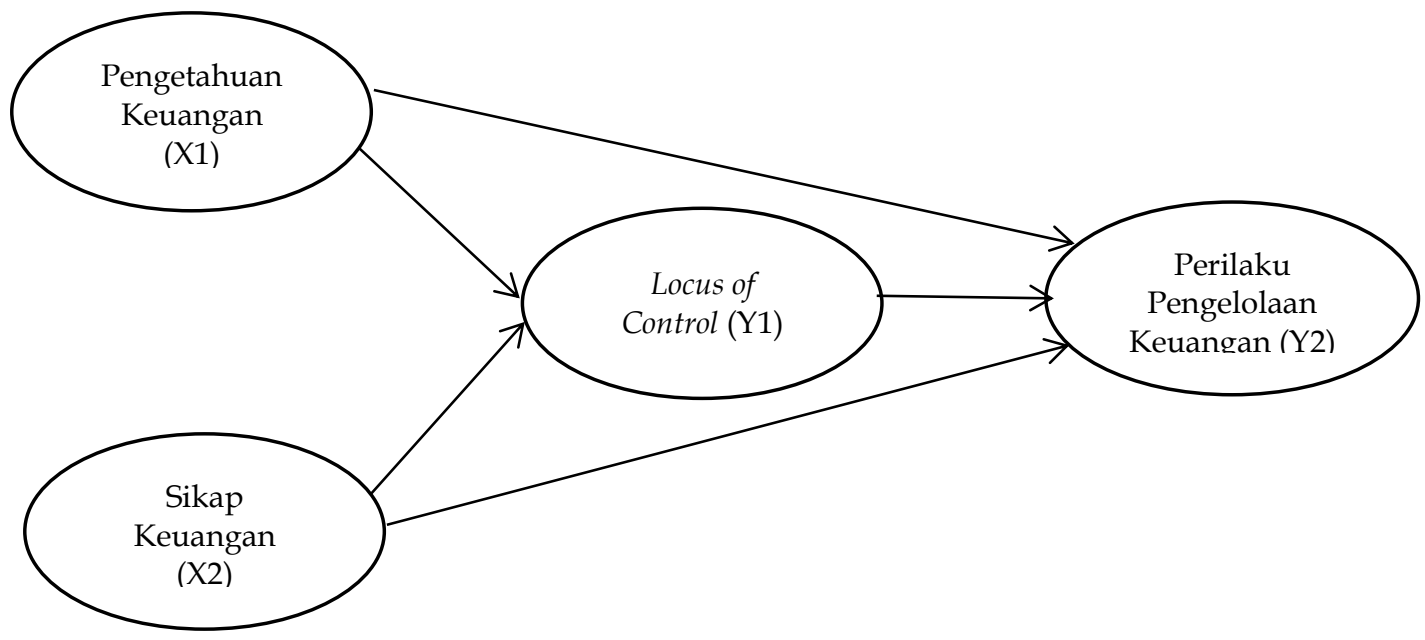

Gambar 1. Model Penelitian

\section{METODE PENELITIAN}

Populasi dalam penelitian ini adalah mahasiswa yang diukur dari mahasiswa fakultas ekonomi perguruan tinggi swasta yang ter-Akreditasi B (Baik) di kota Semarang yang selanjutnya menghasilkan sampel sebanyak 100 responden. Teknik yang digunakan dalam pengambilan sampel adalah proportionate stratified random sampling dan snowball sampling.

Data penelitian menggunakan data primer dengan metode pengumpulan data menggunakan media penyebaran kuesioner yang menggunakan skala interval berupa skala Likert yang menghasilkan jawaban sangat setuju hingga jawaban sangat tidak setuju dengan rentang nilai 1 - 5 (Sugiyono, 2018). Alat analisis yang digunakan dalam penelitian ini adalah analisis data kuantitatif, untuk memperkirakan secara kuantitatif pengaruh langsung maupun tidak langsung dari beberapa variabel independen terhadap variabel dependen. Pengaruh langsung antara variabel independen terhadap variabel independen dapat dilakukan dengan analisis regresi linier berganda. Sedangkan untuk menguji pengaruh tidak langsung terhadap variabel dependen menggunakan analisis jalur (path analysis) dan sobel test. 


\section{HASIL}

Deskripsi Data

Tabel 1. Karakteristik Responden Berdasarkan Jenis Kelamin

\begin{tabular}{|l|c|}
\hline Deskripsi & Jumlah \\
\hline Pria & 32 \\
\hline Wanita & 68 \\
\hline Umur & 24 \\
\hline$\leq 20$ tahun & 69 \\
\hline 20 - 30 tahun & 7 \\
\hline$\geq 30$ tahun & 0 \\
\hline Pendapatan Uang Saku & 63 \\
\hline Rp 100.000 - Rp 500.000 & 37 \\
\hline Rp 500.000 - Rp 1.000.000 & \\
\hline$\geq R p 1.000 .000$ & \\
\hline
\end{tabular}

Sumber: data primer diolah, 2018.

Tabel 2. Nilai Rata-rata Tanggapan Responden

\begin{tabular}{|l|l|l|l|}
\hline No & Variabel & Persentase & Keterangan \\
\hline 1 & Pengetahuan Keuangan & $70,64 \%$ & Cukup Tinggi \\
\hline 2 & Sikap Keuangan & $61,16 \%$ & Sedang \\
\hline 3 & Locus of Control & $79,24 \%$ & Cukup Tinggi \\
\hline 4 & $\begin{array}{l}\text { Perilaku Pengelolaan } \\
\text { Keuangan }\end{array}$ & $89,7 \%$ & Tinggi \\
\hline
\end{tabular}

Sumber : data primer diolah, 2018.

Analisis Regresi Linier Berganda

Tabel 3. Ringkasan Hasil Analisis Regresi Linier Berganda (Persamaan 1)

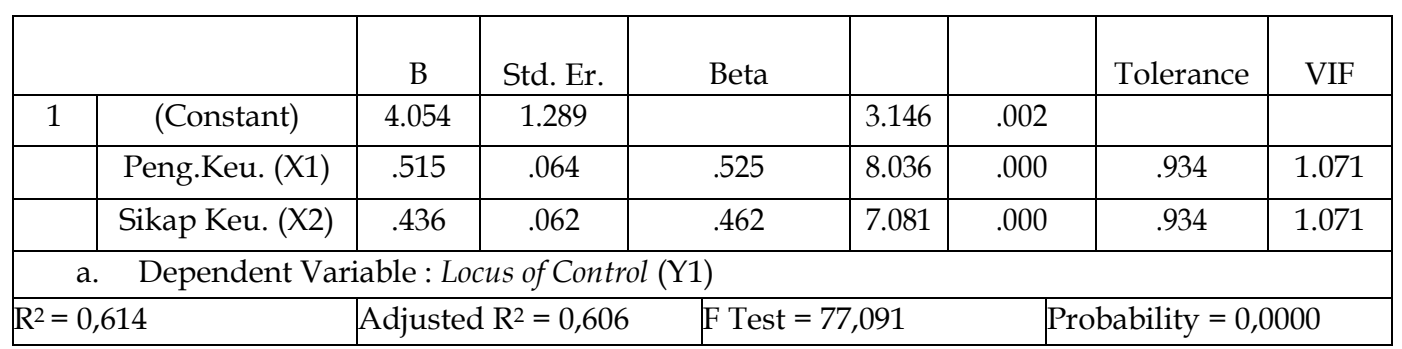

Sumber : data promer diolah, 2018.

Mengacu pada output Regresi Model I pada bagian tabel Coefficients dapat diketahui bahwa nilai koefisien dari kedua variabel bebas yaitu Pengetahuan Keuangan $(X 1)=0,515$ dan Sikap Keuangan $(X 2)=0,436$ dan nilai signifikansi lebih kecil dari 0,05. Hasil ini memberikan kesimpulan bahwa Regresi Model I, yakni variabel Pengetahuan Keuangan (X1) dan Sikap Keuangan (X2) berpengaruh signifikan terhadap variabel Locus of Control (Y1). Besarnya nilai $\mathrm{R}^{2}$ yang terdapat pada Model Summary adalah sebesar 0,614, hal ini menunjukkan 
bahwa kontribusi atau sumbangan pengaruh variabel Pengetahuan Keuangan (X1) dan Sikap Keuangan (X2) terhadap variabel Locus of Control (Y1) adalah sebesar 61,4\% sementara sisanya 38,6\% merupakan kontribusi dari variabelvariabel lain yang tidak dimasukkan dalam penelitian ini. Sementara itu, untuk nilai e1 dapat dicari dengan rumus e1 $=\sqrt{ }(1-0,614)=0,6213$.

Tabel 4. Hasil Analisis Regresi Linier Berganda (Persamaan 2)

Coefficients $^{a}$

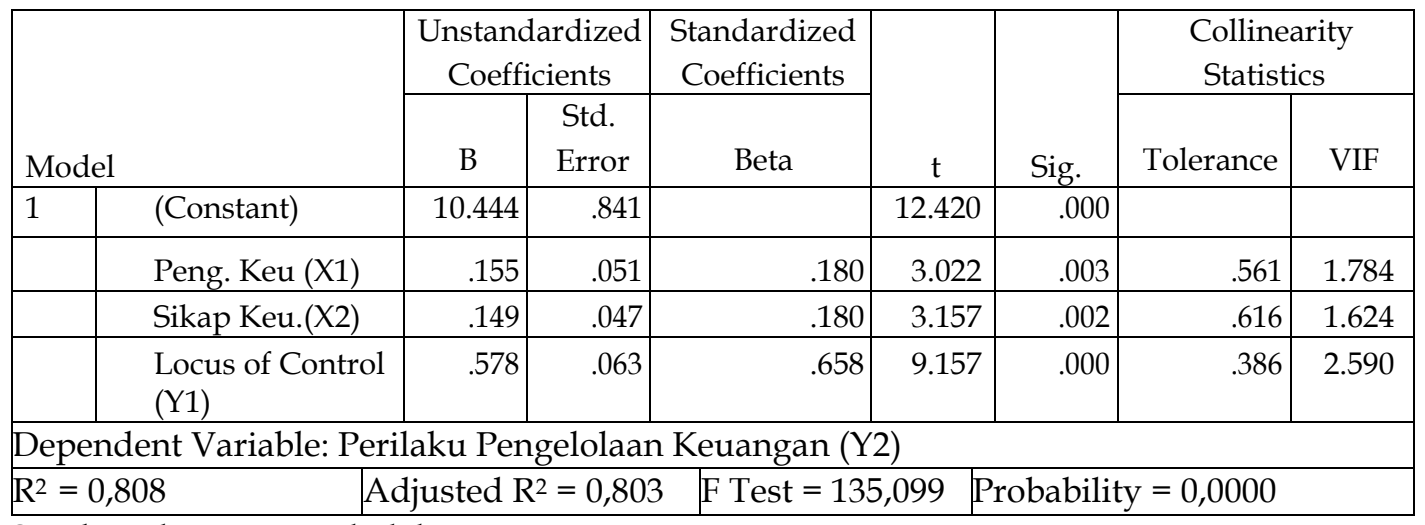

Sumber: data primer diolah, 2018.

Mengacu pada output Regresi Model II pada bagian tabel Coefficients dapat diketahui bahwa nilai koefisien dari ketiga variabel bebas yaitu Pengetahuan Keuangan $(X 1)=0,155$, Sikap Keuangan $(X 2)=0,149$, dan Locus of Control $(\mathrm{Y} 1)=0,578$ dan nilai signifikansi lebih kecil dari 0,05. Hasil ini memberikan kesimpulan bahwa Regresi Model II, yakni variabel Pengetahuan Keuangan (X1), Sikap Keuangan (X2), dan Locus of Control (Y1) berpengaruh signifikan terhadap variabel Perilaku Pengelolaan Keuangan (Y2). Besarnya nilai $\mathrm{R}^{2}$ yang terdapat pada Model Summary adalah sebesar 0,808 , hal ini menunjukkan bahwa kontribusi atau sumbangan pengaruh variabel Pengetahuan Keuangan (X1), Sikap Keuangan (X2), dan Locus of Control (Y1) terhadap variabel Perilaku Pengelolaan Keuangan (Y2) adalah sebesar 80,8\% sementara sisanya 19,2\% merupakan kontribusi dari variabel-variabel lain yang tidak dimasukkan dalam penelitian ini. Sementara itu, untuk nilai e1 dapat dicari dengan rumus e1 $=\sqrt{ }(1$ $0,808)=0,438$.

\section{Analisis Jalur (Path Analysis)}

Analisis jalur digunakan untuk melihat seberapa jauh pengaruh variabel pengetahuan keuangan dan sikap keuangan terhadap perilaku pengelolaan keuangan yang dimediasi oleh locus of control. Model penelitian ini memberikan pengaruh tidak langsung melalui variabel intervening. Uji intervening dilakukan dengan menggunakan uji Sobel. 


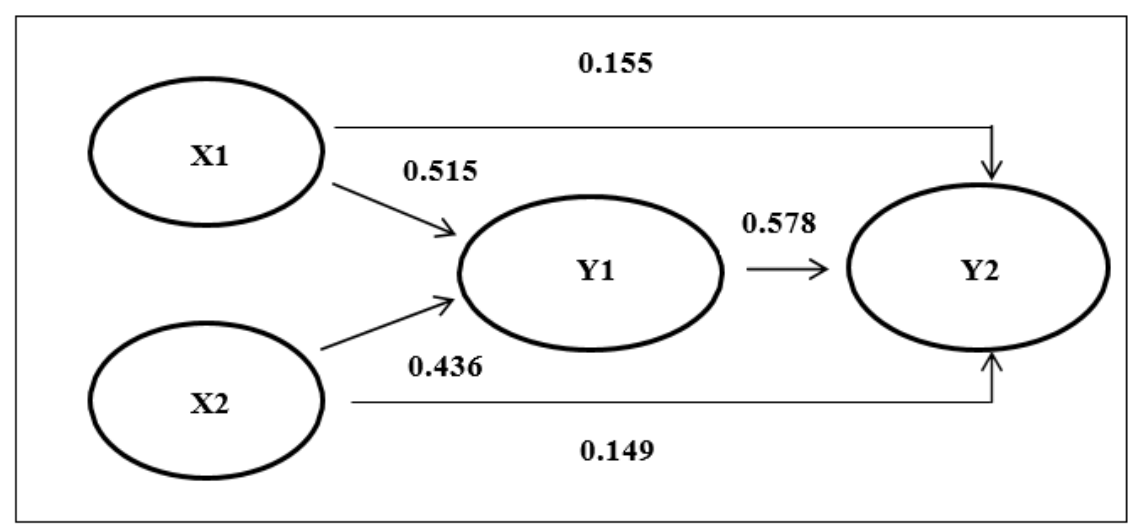

Gambar 2. Analisis Jalur

Sumber : data primer diolah, 2018.

Berdasarkan gambar analisis jalur diajukan hubungan pengetahuan keuangan dan sikap keuangan mempunyai hubungan langsung dengan perilaku pengelolaan keuangan. Namun pengetahuan keuangan dan sikap keuangan mempunyai hubungan tidak langsung ke perilaku pengelolaan keuangan melalui locus of control. Berikut perhitungan mengenai pengaruh variabel independen ke variabeldependen:

1. Perhitungan pengaruh variabel pengetahuankeuangan

- Pengaruh langsung:0.155

- Pengaruh tidak langsung : $0.515 \times 0.578=0.298$

- Total pengaruh : $0.155+0.298=0.453$

2. Perhitungan pengaruh variabel sikap keuangan

- Pengaruh langsung:0.149

- Pengaruh tidak langsung: $0.436 \times 0.578=0.252$

- Total pengaruh : $0,149+0,252=0,401$

Uji Mediasi 1 : Pengaruh Pengetahuan Keuangan terhadap Perilaku Pengelolaan Keuangan yang dimediasi oleh Locus of Ccontrol.

$$
\begin{aligned}
& S a b=\sqrt{b^{2} S a^{2}+a^{2} S b^{2}+S a^{2} S b^{2}} \\
& =\sqrt{(0,578)^{2}(0,064)^{2}+(0,515)^{2}(0,0063)^{2}+(0,064)^{2}(0,063)^{2}} \\
& =0,0493694553 \\
& t=\frac{(0,515)(0,578)}{0,0493694553}=6,0294
\end{aligned}
$$

Dari hasil perhitungan Sobel test di atas mendapatkan nilai $t_{\text {hitung }}=6,0294$, karena nilai thitung yang diperoleh sebesar 6,0294 > nilai t tabel sebesar 1,985 dengan tingkat signifikansi 5\% maka membuktikan bahwa variabel Locus of Control (Y1) mampu memediasi hubungan pengaruh Pengetahuan Keuangan (X1) terhadap Perilaku Pengelolaan Keuangan (Y2). 
Uji Mediasi 2 : Pengaruh Sikap Keuangan terhadap Perilaku Pengelolaan Keuangan yang dimediasi oleh Locus of Control.

$$
\begin{aligned}
& \begin{aligned}
S a b & =\sqrt{b^{2} S a^{2}+a^{2} S b^{2}+S a^{2} S b^{2}} \\
& =\sqrt{(0,578)^{2}(0,062)^{2}+(0,436)^{2}(0,0063)^{2}+(0,062)^{2}(0,063)^{2}} \\
& =0,0453207098
\end{aligned} \\
& t=
\end{aligned}
$$

Dari hasil perhitungan Sobel test di atas mendapatkan nilai $t_{\text {hitung }}=5,5605$,

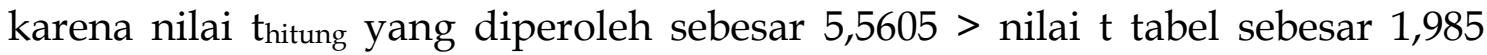
dengan tingkat signifikansi 5\% maka membuktikan bahwa variabel Locus of Control (Y1) mampu memediasi hubungan pengaruh Sikap Keuangan (X2) terhadap Perilaku Pengelolaan Keuangan (Y2).

\section{PEMBAHASAN}

\section{Pengaruh Pengetahuan Keuangan terhadap Locus of Control}

Berdasarkan hasil pengujian maka diketahui bahwa variabel pengetahuan keuangan mempunyai pengaruh yang positif dan signifikan terhadap variabel locus of control pada mahasiswa ekonomi perguruan tinggi swasta yang terakreditasi B dikota Semarang. Maka, dengan demikian menunjukkan bahwa pengetahuan yang dimiliki mahasiswa mampu memiliki kontribusi dalam pengendalian diri yang harus diciptakan. Secara prinsip mahasiswa juga dirasa memahami tata cara pencatatan keuangan dengan benar dan memiliki pengetahuan tentang cara memperoleh dana dengan keseimbangan penggunaan dana secara bijak. Hal ini didukung dengan tanggapan responden yang menghasilkan persentase cukup tinggi.

Pengetahuan keuangan adalah salah satu penunjang pencapaian kualitas hidup yang jauh dari masalah keuangan. Untuk meningkatkan kemampuan individu tersebut, perlu adanya evaluasi kecil yang dilakukan individu dalam hal pengendalian dirinya. Pengendalian diri yang akan membantu individu berpersepsi bahwa segala usaha yang dilakukan akan membawa hasil seimbang dengan edukasi yang dimiliki. Dengan demikian akan membentuk individu berfikir dengan efektif dan efisien dalam hal finansial. Jadi faktor pengetahuan keuangan yang juga berperan penting dalam memutuskan perencanaan investasi, dengan pengetahuan yang dimiliki tentang bagaimana mengelola dan merencanakan keuangan yang dapat memberikan keuntungan dan menghindarkan dirinya dari kerugian.

Sesuai dengan konsep Robbins (2008) tentang bagaimana seseorang dapat mengendalikan nasibnya sendiri, yang terkenal dengan konsep locus of control. Sebagai tindakan dimana individu menghubungkan peristiwa-peristiwa dalam kehidupannya dengan tindakan atau kekuatan dari luar kendalinya. Baranowski, Perry, dan Parcel (1997: 161) menyatakan bahwa "reinforcement is the primary construct in the operant form of learning". Proses penguatan merupakan 
bentuk utama dari cara belajar seseorang. Proses penguatan juga merupakan konsep sentral dari proses belajar sosial. Di dalam teori kognitif sosial, penguatan bekerja melalui proses efek menghalangi (inhibitory effects) dan efek membiarkan (disinhibitory effects). Inhibitory Effects terjadi ketika seseorang melihat seorang model yang diberi hukuman karena perilaku tertentu. Sebaliknya, Disinhibitory Effects terjadi ketika seseorang melihat model yang diberi penghargaan atau imbalan untuk suatu tertentu. Orang akan mengembangkan pengharapan tentang suatu situasi dan pengharapan suatu hasil dari perilakunya sebelum benar-benar mengalami situasi tersebut. Selanjutnya, seseorang mengikat nilai dari pengharapan tersebut dalam bentuk outcome expectancies (harapan akan berhasil). Harapan-harapan ini mempertimbangkan sejauh mana penguatantertentu yang diamati itu dipandang sebagai sebuah imbalan atau pengharapan atau hukuman. Hasil penelitian tersebut sejalan dengan hasil penelitian yang dilakukan oleh Pritazahara (2015), yang menyatakan bahwa pengetahuan keuangan memiliki pengaruh positif dan signifikan pada locus of control.

\section{Pengaruh Sikap Keuangan terhadap Locus of Control}

Berdasarkan hasil pengujian maka diketahui bahwa variabel sikap keuangan mempunyai pengaruh yang positif dan signifikan terhadap variabel locus of control pada mahasiswa ekonomi perguruan tinggi swasta yang terakreditasi B dikota Semarang, sehingga arah pengaruh dari variabel sikap keuangan adalah positif dan signifikan terhadap variabel locus of control pada mahasiswa ekonomi perguruan tinggi swasta yang terakreditasi B di kota Semarang. Sikap keuangan merupakan pemahaman yang membantu individu untuk bersikap rasional dan lebih meningkatkan kepercayaan dirinya dalah hal pemahamannya tentang uang. Sikap keuangan didefinisikan juga sebagai penerapan prinsip-prinsip keuangan untuk menciptakan dan mempertahankan nilai melalui pengambilan keputusan dan pengelolaan sumber daya yang tepat. Hal ini akan tampak dengan tanggapan yang dikeluarkan berupa pernyataan atau opininya tentang uang. Hasil penelitian ini sejalan dengan penelitian yang dilakukan oleh Dwistanti (2017) dengan hasil penelitian bahwa financial attitude memiliki pengaruh positif terhadap kelancaran locus of control.

\section{Pengaruh Pengetahuan Keuangan terhadap Perilaku Pengelolaan Keuangan}

Berdasarkan hasil pengujian maka diketahui bahwa variabel pengetahuan keuangan mempunyai pengaruh yang positif dan signifikan terhadap variabel perilaku pengelolaan keuangan pada mahasiswa ekonomi perguruan tinggi swasta yang terakreditasi B di kota Semarang. Demikian pula dengan hasil deskripsi jawaban responden diperoleh hasil bahwa para mahasiswa tersebut memiliki tingkat pengetahuan keuangan yang cukup tinggi.

Salah satu faktor yang dapat meningkatkan financial knowledge adalah pendidikan (education). Semakin banyak seseorang menerima pendidikan maka financial knowledge orang tersebut juga akan bertambah. Hal ini diakibatkan oleh 
orang-orang berpendidikan akan memilih berbagai tools keuangan (credit card, debit, pay check, obligasi, saham, dll) yang memudahkan mereka untuk melakukan transaksi atau investasi. Orang-orang yang memiliki pendidikan yang lebih tinggi juga akan lebih waspada mengenai masa depan mereka. Sehingga mereka akan lebih banyak mencari tahu mengenai cara-cara untuk menyimpan aset mereka. Hasil penelitian tersebut didukung oleh penelitian yang dilakukan oleh Ida dan Dwitanti(2010) dengan judul penelitian "Pengaruh locus of control, financial knowledge, income terhadap financial management behavior" yang memperoleh hasil bahwa financial knowledege memiliki pengaruh terhadap financial management behavior.

\section{Pengaruh Sikap Keuangan terhadap Perilaku Pengelolaan Keuangan}

Berdasarkan hasil pengujian maka diketahui bahwa ada pengaruh positif dari variabel sikap keuangan terhadap variabel perilaku pengelolaan keuangan pada mahasiswa ekonomi perguruan tinggi swasta yang terakreditasi B di kota Semarang. Hal tersebut memilki arti bahwa semakin baik sikap yang dimiliki seseorang terhadap uang maka semakin baik pula pengelolaan keuangan pribadinya. Demikian pula dengan hasil deskripsi jawaban responden tentang sikap keuangan yang dimiliki mahasiswa ekonomi tersebut termasuk dalam kategori tinggi. Sikap keuangan (financial attitude) yang dimiliki akan membantu para mahasiswa dalam menentukan tindakan dan perilaku mereka dalam hal keuangan, baik dalam hal pengelolaan keuangan, penganggaran keuangan pribadi ataupun keputusan individu mengenai penyimpanan jangka panjang.

Sikap keuangan adalah keadaan pikiran, pendapat, dan penilaian seseorang terhadap keuangan pribadinya, yang kemudian di aplikasikan ke dalam sikap. Pikiran, pendapat dan penilaian seseorang terhadap keadaan keuangan pribadinya akan menentukan tindakan seperti apa yang akan mereka lakukan. Misalnya tabungan, jika seseorang memiliki pikiran, penilaian, dan pendapat bahwa menabung itu tidak penting. Maka orang tersebut tidak akan menabung. Jika pikiran, pendapat, dan penilaian (sikap) ini terus berlanjut maka akan menjadi kebiasaan/perilaku (behavior) yang akan sangat sulit untuk diubah. Hasil penelitian ini sejalan dengan penelitian yang dilakukan oleh Irine dan Damanik (2016) dengan hasil penelitian bahwa financial attitude memiliki pengaruh terhadap kelancaran financial management behavior; dan pada penelitian yang dilakukan oleh Bhushan dan Medury (2014) yang berjudul "An empirical analysis of interlinkages between financial attitude, financial behavior and financial knowledge" yang juga memperoleh hasil yang sama yaitu financial attitude mempengaruhi secara signifikan terhadap financial behavior.

\section{Pengaruh Locus of Control terhadap Perilaku Pengelolaan Keuangan}

Berdasarkan hasil pengujian maka diketahui bahwa pengaruh dari variabel locus of control adalah positif dan signifikan terhadap variabel perilku pengelolaan keuangan pada mahasiswa ekonomi perguruan tinggi swasta yang terakreditasi B di kota Semarang. Demikian pula dengan hasil deskripsi jawaban responden tentang locus of control yang dimiliki mahasiswa ekonomi tersebut 
termasuk dalam kategori tinggi, mereka mampu mengendalikan apapun bentuk pengeluaran yang dirasa tidak penting dan merusak pengelolaan keuangan yang sudah ditetapkan.

Pengaruh positif ini menunjukkan bahwa semakin tinggi locus of control individu, maka semakin baik perilaku pengelolaan keuangannya. Kholilah dan Iramani (2013) menyatakan bahwa locus of control merupakan variabel psikologis, oleh karena itu bersifat kecenderungan. Locus of control dalam psikologi sosial mengacu pada sejauh mana individu yakin bahwa mereka dapat mengontrol kejadian-kejadian yang mempengaruhi perilaku mereka. Hasil penelitian ini sejalan dengan penelitian yang dilakukan oleh Zaniati (2017) dengan hasil penelitian bahwa locus of control berpengaruh positif dan signifikan terhadap perilaku pengelolaan keuangan.

Pengaruh Pengetahuan Keuangan terhadap Perilaku Pengelolaan Keuangan yang dimediasi oleh Locus of Control

Berdasarkan hasil pengujian maka diketahui bahwa variabel locus of control mampu memediasi pengaruh pengetahuan keuangan terhadap perilaku pengelolaan keuangan. Hal itu sejalan dengan kontrol diri yang dimiliki oleh mahasiswa sehingga edukasi mahasiswa mampu sejalan dengan kontrol diri dan membentuk karakter untuk pengelolaan keuangan pribadinya. Hasil penelitian ini sejalan dengan penelitian sebelumnya yang dilakukan oleh Perry dan Morris (2005) yang berjudul "Who is in control? The role of self-perseption, knowledge, and income in explaining consumer financial behavior" menyatakan bahwa hubungan antara financial knowledge dan perilaku pengelolaan keuanganyang bertanggung jawab dimediasi oleh pengaruh locus of control.

Pengaruh Sikap Keuangan terhadap Perilaku Pengelolaan Keuangan yang dimediasi oleh Locus of Control

Berdasarkan hasil pengujian maka diketahui bahwa variabel locus of control mampu memediasi pengaruh sikap keuangan terhadap perilaku pengelolaan keuangan. Hasil penelitian lapangan oleh peneliti memperoleh hasil bahwa mahasiswa ekonomi perguruan tinggi swasta di kota Semarang tergolong cukup tinggi terkait dengan pengetahuan terhadap uang. Hal itu sejalan dengan kontrol diri yang dimiliki oleh mahasiswa sehingga edukasi mahasiswa mampu sejalan dengan kontrol diri dan membentuk karakter untuk pengelolaan keuangan pribadinya.

Pengelolaan keuangan memiliki pengaruh terhadap pengelolaan yang ada pada mahasiswa ekonomi di perguruan tinggi swasta di kota Semarang. Semakin besar jumlah mahasiswa yang mampu mengelola keuangan pribadinya maka akan semakin besar pula pengaruh yang akan diberikan kepada mahasiswa lain untuk mengelola keuangan dengan baik. Dengan adanya penelitian ini, diharapkan dapat menjadikan sumber informasi preferensi mahasiswa tentang uang, serta selaras dengan sikap dan pengendalian diri yang dimilikinya. 
Hasil deskripsi jawaban responden rata-rata memberikan penilain dalam kategori cukup tinggi terhadap variabel locus of control. Hal ini berarti mahasiswa mampu meminimalisir lagi pengeluaran - pengeluaran diluar rencana sehingga pola yang tahan dengan pengaruh dari lingkungan dapat terbentuk menjadi lebih baik lagi. Dengan usaha - usaha tersebut, mahasiswa akan lebih memiliki inisiatif yang cenderung lebih baik untuk pemecahan masalahnya terhadap uang.

\section{DAFTAR PUSTAKA}

Ajzen, I. 1991. Theory of Planned Behavior. Organizational Human Behavior and Human Decision Processes. 50, 179-211.

Ajzen. 2006. The theory of planned behavior. Tersedia di http://people.umass. edu/aizen/tpb.html.

Ajzen, I., \& Fishbein, M., 1975, Belief, Attitude, Intention, and Behavior: An Introduction to Theory and Research, 129-385, Addison-Wesley, Reading, MA.

Bandura, A.1962. Social learning through imitation. Dalam M.R. Jones (Ed), Nebraska symposium on motivation.Vol 10. Lincoln: University of Nebraska Press

Bandura, A. 1977a. Self-Efficacy: Toward a unifying theory of behavior change. Psychological Review, 84, hal. 191-215

Bandura, A. 1977b. Social Learning Theory. New Jersey: Prentice Hall

Baran, S.J \& D.K. Davis. 2000. Mass Communication Theory: Foundations, Ferment, and Future. 2nd edition. Belmont, CA: Wadsworth

Baranowsky, T, C.L. Perry \& G.S. Parcel. 1997. How Individuals, environments, and health behavior interact: Social Cognitive Theory. Dalam K. Glanz, F.M. Lewis, \& BK Rimer, Health Behavior and Health Education: Theory, Research, and Practice. 2nd edition. San Francisco: Jossey-Bass

Chowa, Gina A.N., Despard Mat, dan Akoto Isaac Osei. 2012. Financial Knowledge and Attitudes of Youth in Ghana. Youth Save Research Brief.

Hilgert, Marianne A., Jeanne M. Hogarth dan Sondra Baverly. 2003. Household Financial Management: The Connection between Knowledge and Behavior. Federal Reserve Bulletin, 89(7):309-322

Humaira, Iklima dan Sagoro, Endra Murti. 2018. Pengaruh Pengetahuan Keuangan, Sikap Keuangan dan Kepribadian terhadap Perilaku Manajemen Keuangan pada Pelaku UMKM Sentra Kerajinan Batik Kabupaten Bantul. Jurnal Nominal Vol. 7 No. 1

Ida dan Dwinta. C.Y., 2010. Pengaruh locus of control, financial knowledge, income terhadap financial management behavior. Jurnal Bisnis dan Akuntansi Vo.12 No.3:131-144

Irine, Herdjiono dan L.A. Damanik. 2016. Pengaruh financial attitude, financial knowledge, parental income terhadap financial management behavior. Jurnal Managemen Teori dan Terapan Tahun 9 No. 3 
Kholilah, N.A dan Irmani, Rr. May 2013. Studi Financial Management Behavior Pada Masyarakat Surabaya. Journal of Business and Banking Volume 3, No. 1, May 2013, pages 69 - 80.

Kurniawati, ID. dan Lestari, Wiwiek. 2017. Pengaruh Sikap Terhadap Uang Dan Pengetahuan Keuangan Dengan Mediasi Locus Of Control Terhadap Perilaku Pengelolaan Keuangan Keluarga.

http:/ /library.binus.ac.id/eColls/eThesisdoc/Bab2HTML/2012201302MCBab2 001/page32.html

Marsh, Brant A. (2006). Examining The Personal Finance Attitudes, Behaviors, And Knowledge Levels Of First-Year And Senior Students At BaptistUniversities In The State Of Texas. Disertasi.

Nur Riska, Agustina. 2018. Pengaruh financial knowledge dan financial attitude terhadap financial management behavior dimediasi oleh locus of control: Studi pada mahasiswa jurusan manajemen Fakultas Ekonomi Universitas Islam Negeri Maulana Malik Ibrahim Malang, Tesis, UIN-Malang.

Perry, Vanessa G., Marlene D Morris. (2005). Who is in Control? The Role of Self Perception, Knowledge, and Income in Explaining Consumer Financial Behavior. The Journal of Consumer Affairs, 39 (2), 299:313

Pritazahara, Ritma. \& Sriwidodo, Untung. 2015. Pengaruh Pengetahuan Keuangan dan Pengalaman Keuangan Terhadap Perilaku Perencanaan Investasi Dengan Self Control Sebagai Variabel Moderating. Jurnal Ekonomi dan Kewirausahaan, Vol. 15 (No. 1), hal 28-37.

Puneet, B., Yajulu Medury. (2014). An Empirical Analysis of Intern Lingkages Between Financial Attitudes, Financial Behavior and Financial Knowledge of Salaried Individuals. Indian Jornal of Commerce $\mathcal{E}$ Management Studies, 5 (3), 58-64.

Rajna, A., Ezat, W.P.S., Junid, S.A., Moshiri, H. 2011. Financial Management Attitude and Practice among the Medical Practitioners in Public and Private Medical Service in Malaysia. International Journal of Business and Management Vol. 6, No. 8 Hal. 105-113. Retrieved from www.ccsenet.org/ijbm.

Robbins, S.P, 2008, Organizational Behavior: Concepts, Controversies, Applications. Twelfth Edition. Prentice Hall International: New Jersey.

Rotter, J., 1966. Generalized expectancies for internal versus external control of reinforcement. Psychological Monographs: General and Applied.

Rustiaria, Annora Paramitha. 2017. Pengaruh pengetahuan keuangan, sikap keuangan dan tingkat pendidikan terhadap perilaku pengelolaan keuangan. Artikel Ilmiah

Sugiyono. 2017. Metode penelitian pendidikan pendekatan kuantitatif, kualitatif dan R\&D. Bandung. Alfabeta

Taneja, R. M. 2012. Money attitude- an abridgement. Journal of Arts, Science $\mathcal{E}$ Commerce. Vol.3 No.3 : 94-98.

Wahyono, Budi. 2014. Teori Perilaku Yang Direncanakan (Theory of Planned Behavior). 